\title{
Inhaled nitric oxide: an sGC-dependent IOP lowering agent
}

\author{
Wolfgang S Lieb', Stefan Munster ${ }^{1}$, Ana C Dordea', Sara Vandenwijngaert ${ }^{1}$, Robert E Tainsh ${ }^{1}$, Peter Brouckaert $^{2}$, \\ Warren M Zapol1, Emmanuel S Buys ${ }^{1 *}$
}

From 7th International Conference on cGMP Generators, Effectors and Therapeutic Implications Trier, Germany. 19-21 June 2015

\section{Background}

The nitric oxide (NO)-soluble guanylate cyclase (sGC)cyclic guanosine 3'5'-monophosphate (cGMP) pathway regulates intraocular pressure (IOP). Preclinical and clincial studies have demonstrated the ability of NO-donor compounds to lower IOP (e.g. VESNEO ${ }^{\circledR}$ ). The use of inhaled NO gas (iNO), a specific pulmonary but not systemic vasodilator, is an approved therapy for pulmonary hypertension and is under development as a treatment for other cardiovascular diseases (e.g. for myocardial ischemia, the NOMI trial). We hypothesized that breathing $\mathrm{NO}$ lowers IOP in an sGC-dependent manner.

\section{Methods}

Anesthetized IOP model: 10 - to 20 -week-old male wildtype (WT) mice and mice deficient in the $\alpha 1$-subunit of sGC (sGC $\alpha 1^{-1-}$ mice; $n=9$, each) were anesthetized with isoflurane using a standard protocol resulting in a stable IOP baseline. Ten minutes after baseline measurement, IOP was measured again in mice breathing $1.8 \%$ isoflurane and either control gas $\left(\mathrm{N}_{2}\right.$ balanced in $\left.\mathrm{O}_{2}\right)$ or $40 \mathrm{ppm}$
NO balanced in $\mathrm{O}_{2}$. Awake IOP model: WT mice were acclimated to awake IOP measurements (every other day for 2 weeks). 40 min after baseline measurements, IOP was measured in mice breathing either control gas or $40 \mathrm{ppm}$ iNO $(\mathrm{n}=8$, each) in an incubation chamber.

\section{Results}

Breathing control gas did not affect IOP in WT or $\mathrm{sGC \alpha}^{-1-}$ mice (Figure 1). Breathing iNO decreased IOP in both anesthetized WT mice $(9.86 \pm 0.31$ vs. $8.42 \pm 0.51$ $\mathrm{mmHg}$ at baseline and after iNO, respectively, Figure 1a) and awake WT mice $(14.13 \pm 1.95$ vs. $10.93 \pm 1.01 \mathrm{mmHg}$, at baseline and after $40 \mathrm{~min}$ iNO, respectively, Figure 1b). In contrast, $\mathrm{iNO}$ did not lower IOP in $\mathrm{sGC} \alpha 1^{-1-}$ mice $(9.75 \pm 0.31$ vs. $9.46 \pm 0.30 \mathrm{mmHg}$ at baseline and after iNO, respectively, Figure 1a).

\section{Conclusion}

Inhalation of $40 \mathrm{ppm}$ iNO decreased IOP in anesthetized and awake WT mice but not in sGCa1-/- mice. These findings confirm that NO is an IOP-lowering

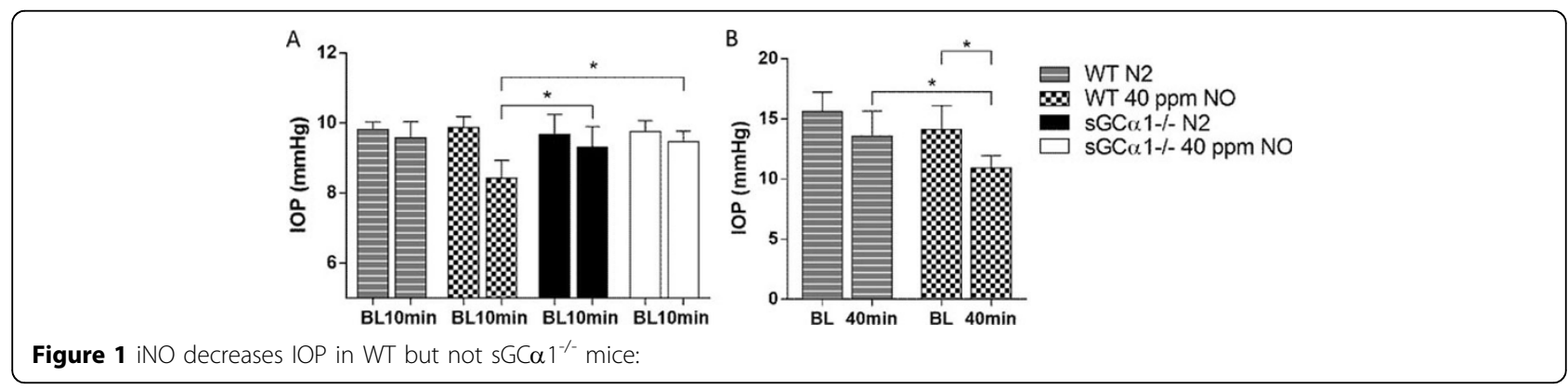

\footnotetext{
* Correspondence: ebuys@mgh.harvard.edu

${ }^{1}$ Department of Anesthesia, Critical Care, and Pain Medicine, Massachusetts

General Hospital and Harvard Medical School, Boston, 02114, MA, USA

Full list of author information is available at the end of the article
} 
agent, and identify $\mathrm{NO}$-gas as a possible therapeutic approach to acutely lower IOP. In addition, our results identify sGC as the downstream target of NO's ability to lower IOP. sGC stimulators, under development for treatment of cardiovascular diseases, such as the recently approved $A D E M P A S^{\circledR}$, may be considered as a novel treatment option for elevated IOP.

\section{Authors' details}

'Department of Anesthesia, Critical Care, and Pain Medicine, Massachusetts General Hospital and Harvard Medical School, Boston, 02114, MA, USA.

${ }^{2}$ Department for Biomedical Molecular Biology, Ghent University, Ghent 9000, Belgium.

Published: 2 September 2015

doi:10.1186/2050-6511-16-S1-A38

Cite this article as: Lieb et al:: Inhaled nitric oxide: an sGC-dependent IOP lowering agent. BMC Pharmacology and Toxicology 2015 16(Suppl 1): A38.

Submit your next manuscript to BioMed Central and take full advantage of:

- Convenient online submission

- Thorough peer review

- No space constraints or color figure charges

- Immediate publication on acceptance

- Inclusion in PubMed, CAS, Scopus and Google Scholar

- Research which is freely available for redistribution

Submit your manuscript at www.biomedcentral.com/submit 